Research Article

\title{
Compact Ultrawide Band Metamaterial-Inspired Split Ring Resonator Structure Loaded Band Notched Antenna
}

\author{
Kapil Jairath $\mathbb{D},{ }^{1}$ Navdeep Singh $\mathbb{D},{ }^{2}$ Vishal Jagota $\mathbb{D},{ }^{3}$ and Mohammad Shabaz $\mathbb{D}^{4}$ \\ ${ }^{1}$ Department of Applied Science, IKGPTU, Kapurthala, Punjab, India \\ ${ }^{2}$ Department of Applied Science, ACET, Amritsar, Punjab, India \\ ${ }^{3}$ Department of Mechanical Engineering, Madanapalle Institute of Technology \& Science, Madanapalle, AP, India \\ ${ }^{4}$ Arba Minch University, Arba Minch, Ethiopia \\ Correspondence should be addressed to Mohammad Shabaz; mohammad.shabaz@amu.edu.et
}

Received 28 April 2021; Revised 10 May 2021; Accepted 21 May 2021; Published 30 May 2021

Academic Editor: Vijay Kumar

Copyright (๑) 2021 Kapil Jairath et al. This is an open access article distributed under the Creative Commons Attribution License, which permits unrestricted use, distribution, and reproduction in any medium, provided the original work is properly cited.

\begin{abstract}
A novel compact size ultrawide band planar antenna with band notched characteristics is present. The band rejection characteristic is achieved by loading a pair of metamaterial inspired rectangular split ring resonator (SRR) near the feed line and by etching the SRR slots on a radiating patch. The simulated and measured results reveal that the proposed antenna exhibits the impedance bandwidth over the ultrawide band (UWB) frequency range from 3.1 to $14 \mathrm{GHz}$ with the voltage standing wave ratio less than 2 except for band stop bands at 3.29 to $3.7 \mathrm{GHz}$ (WiMAX band), 3.7 to $4.10 \mathrm{GHz}$ (C-band), 5.1 to 5.9 GHz (WLAN band), and 7.06 to $7.76 \mathrm{GHz}$ (downlink X-band satellite communication), respectively. The proposed antenna fabricated on low-cost FR4 substrate has compact size of $24 \times 20 \times 1.6 \mathrm{~mm}^{3}$. The simulation results are compared with measured results and demonstrate good agreement with stable gain over pass bands. The proposed antenna also exhibits dipole-like radiation pattern in E-plane and omni-directional pattern in H-plane. These results led to conclusion that the presented antenna is a suitable candidate for ultrawide band UWB applications with desired band notch characteristics.
\end{abstract}

\section{Introduction}

Since the allocation of the frequency range for unlicensed radio application by FCC (Federal Communications Commission) having the bandwidth of $7.5 \mathrm{GHz}(3.1-10.6 \mathrm{GHz})$, ultrawide band UWB technology has attracted much attention in communication system. This technology is growing rapidly day by day with advancement in the variety of applications such as radio sensing, body area networking, and short-range broadband communication [1]. The patch containing radiator antennas is widely used in order to implement ultrawide band communications which have been analyzed by using various feeding techniques viz. microstrip line feed, coplanar waveguide feed, coaxial feed, etc. [2-5]. However, it is always a challenge to design ultrawide band antenna along with stable gain, compact size, and filtering characteristics which can eliminate the coexisting narrow band communication such as WiMAX band $(3.3-3.7 \mathrm{GHz})$, C-band $\quad(3.7-4.2 \mathrm{GHz})$, WLAN band
(5.1-5.8 GHz), and X-band satellite communication $(7.1-7.9 \mathrm{GHz})[6-8]$. Metamaterials are the artificial engineered magnetic materials which can be used to obtain and improve the band notching characteristics in ultrawide band antennas. The MTMs are made up of subwavelength structures which help in attaining negative permittivity and permeability in the structures at certain resonant frequencies. Split ring resonators (SRR) and complementary split ring resonators (CSRR) are examples of mostly utilized MTM structures for achieving band notching in ultrawide band antennas $[9,10]$. These structures are capable of rejecting the interfering narrow band frequencies without degrading the other performance characteristics antenna. Coupling between the two ring resonator structures having different resonant frequencies is done to achieve new resonant frequency and obtain desired results.

Various researchers used different techniques to mitigate the electromagnetic interference with the above said narrow bands. Band notched characteristics are realized by adding 
half or quarter wavelength $[11,12]$ and by using embedding different types of slots such as T-shaped [13], Z-shaped [14], C-shaped, H-shaped, U-shaped, or L-shaped [15-17], arcshaped $[18,19]$, pi-shaped [20], and omega-shaped on the ground plane or on the radiating patch. Some researchers use other techniques which are parasitic elements [21, 22], pin diodes [23], multimode resonators [24], frequency selective surface patch [25], tri-arm resonator [26], and mushroom-type EBG (electromagnetic band gap) structure to achieve frequency rejection characteristics.

Nowadays, metamaterial-inspired resonator viz. SRR and CSRR [27] structures are commonly used to accomplish the filtration of interfering bands. Split ring resonator (SRR), sometimes also called Negative refractive index material (NRIM), has capability to control and channelize electromagnetic waves $[28,29]$ which was presented in [30]. The SRR structure can also be used as a slot for rejecting bands as carried out in $[31,32]$. Understand the further concepts on optimization [33-36]. The complementary split ring resonator (CSRR) which is negative reflection of the split ring resonator (SRR) can be used as periodic structure of metamaterial and has attracted much attention of various researchers to be used as frequency selective structure [37-43].

In this paper, a novel miniaturized ultrawide band UWB antenna with unwanted band rejection application is proposed. Two circular shape stub and rectangular stub is introduced on the ground plane to achieve the large impedance bandwidth from $3 \mathrm{GHz}$ to $14 \mathrm{GHz}$. The rejection of worldwide interoperability for microwave access WiMAX band (3.3 to 3.7 GHz) and C-band (3.7 to $4.2 \mathrm{GHz}$ ) is acquired by etching the metamaterial-inspired split ring resonator (SRR) slot on the radiator. The wireless local area network WLAN band (5.1 to $5.8 \mathrm{GHz}$ ) is achieved by embedding the metamaterial resonator (RSRR) near the microstrip feed line, and the downlink of X-band satellite communication frequency is rejected by employing single CSRR slot on the radiator patch. The performances of designed antenna are studied by using HFSS, and simulated results are compared with the measured results. The presented paper is arranged in the following manner. Section 2 presents the configuration and design of proposed antenna. Section 3 presents and analyzes the simulated and measured results and further the experimental results of the presented antenna are compared with existing antennas, and Section 4 concludes the paper.

\section{Configuration and Design of Band Notched UWB Antenna}

The schematic of proposed band notched UWB antenna is shown in Figure 1. The prototype is designed and augmented using high-frequency simulation software HFSS 15 and is represented in Figures 1(a) and 1(b). The proposed antenna consists of the rectangular patch with two elliptical stubs at two lower corner of the patch and two circular stubs at the upper edge of the ground plane and one rectangular cut at the centre of the ground plane. The suggested antenna has miniaturized size of $24 \mathrm{~mm} \times 20 \mathrm{~mm}\left(L_{s} \times W_{s}\right)$ and is mounted on low-cost FR-4 substrate having thickness of $1.6 \mathrm{~mm}$, relative dielectric constant of 4.4 , and loss tangent $(\tan \delta)$ of 0.02 . The metamaterial unit cell near the feed line and metamaterial-inspired SRR slot on the top of the radiating patch are incorporated in order to attain band notching characteristics. The detailed dimensions of proposed metamaterial-inspired SRR loaded band stop antenna is represented in Table 1 . Table 2 represents the detailed geometry of the metamaterial unit cell.

The proposed antenna started with the rectangular radiator of size $10 \mathrm{~mm} \times 12 \mathrm{~mm}\left(L_{p} \times W_{p}\right)$ which is fed by 50 ohm microstrip feed line of size $10 \mathrm{~mm} \times 2.5 \mathrm{~mm}\left(L_{f} \times W_{f}\right)$. The ground plane of size $8 \mathrm{~mm} \times 20 \mathrm{~mm}\left(L_{g} \times W_{g}\right)$ is printed on the back side of the substrate. It can be seen that, by inclusion of the elliptical shaped notches at the lower corner of the radiator patch and circular notches at upper edges of the ground plane, the enhanced impedance bandwidth of the suggested antenna is achieved due to electromagnetic coupling between the rectangular radiator and the partial ground plane. The two band notches at WiMAX $(3.29-3.7 \mathrm{GHz})$ and C-band $(3.7-4.1 \mathrm{GHz})$ are achieved by etching the metamaterial-inspired split ring resonator SRR slot on the top of the radiating patch. The next frequency notch at the WLAN band $(5.1-5.9 \mathrm{GHz})$ is obtained by embedding a pair of rectangular metamaterial-inspired SRR near the feed line of the antenna. The downlink X-band $(7.06-7.76 \mathrm{GHz})$ is rejected by employing the split ring circular slot at the centre of the radiator. The fabricated prototype is represented in Figure 2. We further used the methods to optimise the technique $[44,45]$. The length of etched slots should be one half of guided wavelength at desired notched band frequency [46]. The length of each slot can be premeditated using equations (1) and (2) as follows:

$$
\begin{aligned}
f_{\text {notch }} & =\frac{c}{2 L_{\text {slot }} \sqrt{\varepsilon_{\text {eff }}}}, \\
\varepsilon_{\text {eff }} & =\frac{\varepsilon_{r}+1}{2} .
\end{aligned}
$$

Figures 3 and 4 illustrate the reflection coefficient and voltage standing wave ratio (VSWR) results for the evolution of the proposed antenna. It can be seen from figures that the proposed antenna exhibits the band notching at WiMAX band, C band, WLAN band, and downlink X-band by employing the metamaterial-inspired SRR structures and slots on the radiating patch. The characterisation of the metamaterial unit cell is represented in Figures 5 and 6. The scattering parameters such as reflection coefficient $\left(S_{11}\right)$ and transmission coefficient $\left(S_{21}\right)$ of the SRR structure are achieved by exciting the structure with electromagnetic waves. The simulated result shows that the metamaterial unit cell exhibits the stop band characteristics at $5.5 \mathrm{GHz}$. The impedance $(Z)$ versus frequency graph depicts the stop band characteristics of the unit cell. At band notched frequency, the value of input resistance and input reactance are not around nominal values, i.e., $50 \mathrm{ohms}$ and zero ohm. The negative permittivity and permeability of the metamaterial-inspired SRR unit cell are extracted by calculating the values of refractive index and wave impedance from the $S$-parameters. Figure 7 represents the extracted negative permittivity and negative permeability of the metamaterial-inspired SRR unit cell. 


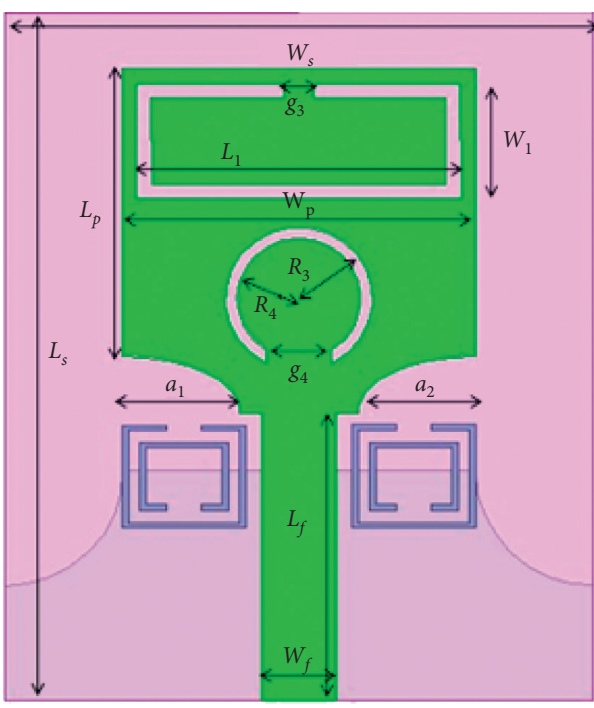

(a)

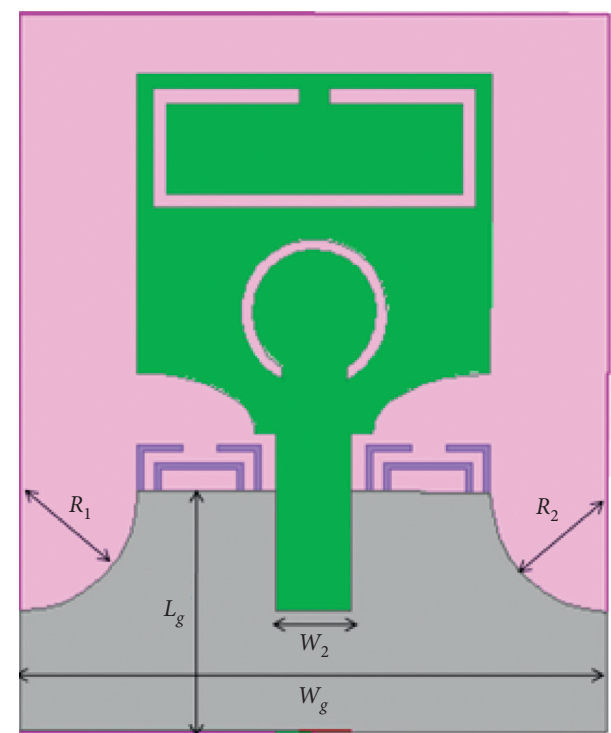

(b)

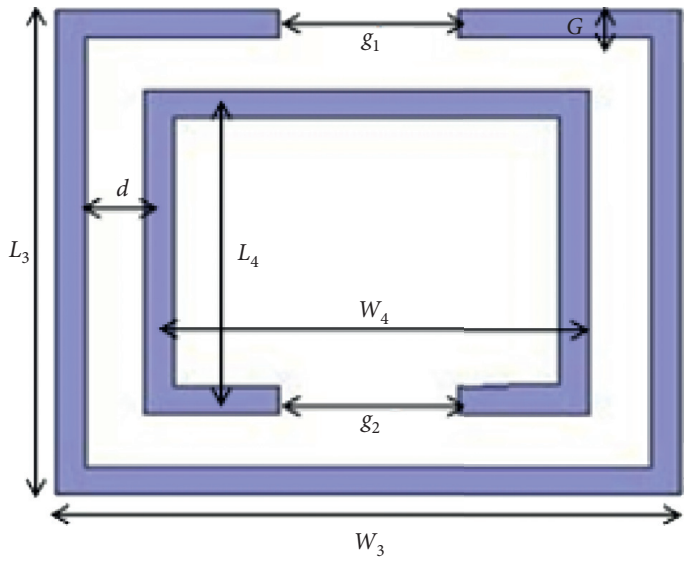

(c)

FIgURE 1: Layout of proposed band notched antenna. (a) Top side. (b) Bottom side. (c) Metamaterial unit cell.

TABLE 1: Detailed dimensions in $\mathrm{mm}$ of the proposed band notch antenna.

\begin{tabular}{lccccccccccccccccccccccccc}
\hline Parameters & $L_{s}$ & $W_{s}$ & $L_{p}$ & $W_{p}$ & $L_{g}$ & $W_{g}$ & $L_{f}$ & $W_{f}$ & $L_{1}$ & $W_{1}$ & $L_{2}$ & $W_{2}$ & $S$ & $R_{1}$ & $R_{2}$ & $R_{3}$ & $R_{4}$ & $g_{1}$ & $g_{2}$ & $g_{3}$ & $g_{4}$ & $a_{1}$ & $a_{2}$ & $t$ & $h$ \\
\hline Unit & 24 & 20 & 10 & 12 & 8 & 20 & 10 & 2.5 & 11 & 4 & 4 & 2.5 & 0.5 & 4 & 4 & 2.5 & 2.1 & 1.2 & 1.2 & 1 & 2.2 & 2 & 2 & 0.4 & 1.6 \\
\hline
\end{tabular}

TABLE 2: Detailed dimensions in $\mathrm{mm}$ of the metamaterial unit cell.

\begin{tabular}{lcccccccc}
\hline Parameters & $L_{3}$ & $W_{3}$ & $L_{4}$ & $W_{4}$ & $g_{1}$ & $g_{2}$ & $d$ & $G$ \\
\hline Unit & 3.6 & 4.2 & 3.2 & 3.8 & 1.2 & 1.2 & 0.4 & 0.4 \\
\hline
\end{tabular}

\section{Results and Discussion}

In this section, the simulated result of the proposed antenna is discussed and the proposed antenna is optimized by analysing the simulated results of voltage standing wave ratio, gain of antenna, radiation pattern, and radiation efficiency, respectively. The parametric study is carried out for optimization of performances of the proposed band notched antenna. The proposed band notched antenna is analyzed by using high-frequency simulation software (HFSS). During the parametric study, the effect of variation of dimensions of the rectangular split ring resonator (SRR) structure, SRR slot, and circular shaped split ring slot is investigated.

Figure 8 illustrates the optimization of gap $g_{1}$ and $g_{2}$ of the metamaterial-inspired SRR structure on the basis of voltage standing wave ratio (VSWR). The dimension of gap $g_{1}$ and $g_{2}$ is varied from $1.12 \mathrm{~mm}$ to $1.24 \mathrm{~mm}$ for optimization of WLAN band rejection frequency. It can be observed that rejected WLAN band $(5.1-5.9 \mathrm{GHz})$ exhibits the peak VSWR value of 6.04 at frequency $5.5 \mathrm{GHz}$. The increase in the gap value $g_{1}$ and $g_{2}$ of the metamaterial-inspired SRR structure leads to small decrease in the total inductance and the gap capacitance of the resonator structure, which helps in achieving the desired rejected frequency of the WLAN 


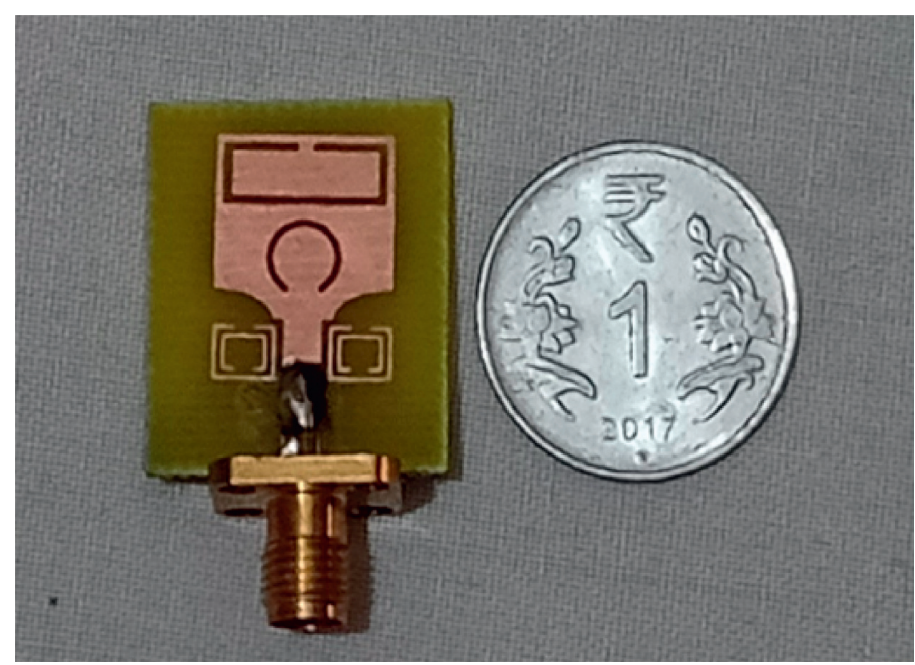

(a)

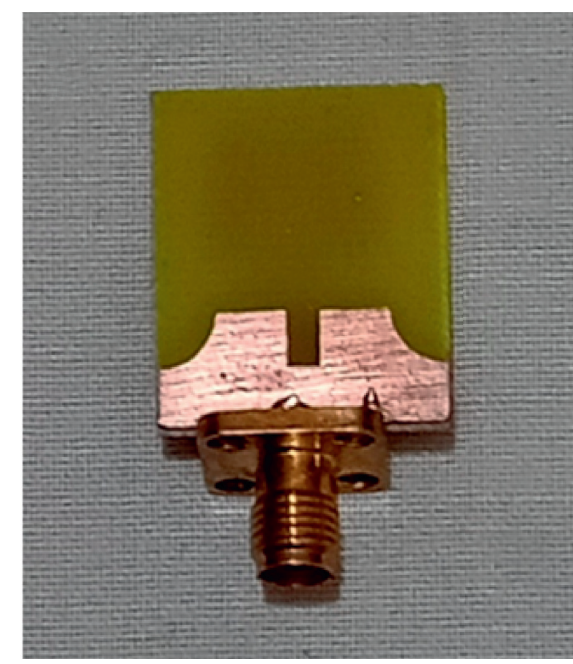

(b)

FIGURE 2: Fabricated proposed antenna. (a) Front side. (b) Back side.
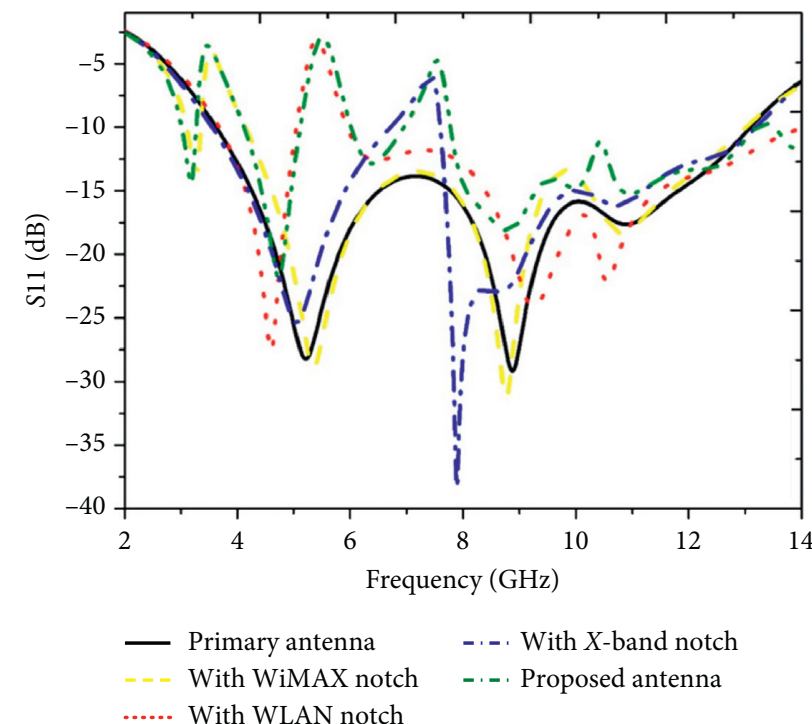

-... With $X$-band notch

-. - . Proposed antenna

FIGURE 3: Reflection coefficient results for the proposed antenna.

band. Figure 8 depicts the gap variation of the split ring resonator metamaterial slot for optimization of WiMAX band and C-band notch characteristics.

The value of $g_{3}$ is increased from $0.5 \mathrm{~mm}$ to $2 \mathrm{~mm}$ with step size of $0.5 \mathrm{~mm}$ for achieving the WiMAX band and C-band notching. It has been observed from Figure 9 that when the value of gap is taken equal to $0.5 \mathrm{~mm}$, the rejected band exhibits peak VSWR 5.11 at frequency $3.3 \mathrm{GHz}$. When the gap value is increased in step size of $0.5 \mathrm{~mm}$, rejected band exhibits the peak VSWR 5.08 at $3.5 \mathrm{GHz}, 4.94$ at $3.5 \mathrm{GHz}$, and 5.07 at $3.6 \mathrm{GHz}$. It is noticed that the rejected band does exhibit required band notching frequency when the gap value $g_{3}$ is taken as $0.5 \mathrm{~mm}, 1.5 \mathrm{~mm}$, and $2 \mathrm{~mm}$, and it can be concluded that, at $g_{3}=1 \mathrm{~mm}$, WiMAX and C-band rejection is stronger and hence accomplished.

Figure 10 describes the VSWR variation of gap $g_{4}$ for optimization of downlink X-band satellite communication rejection characteristics. The value of gap $g_{4}$ is varied from $2.16 \mathrm{~mm}$ to $2.2 \mathrm{~mm}$ with the increase in the value having step size of $0.2 \mathrm{~mm}$. It can be seen from Figure 9 that the rejected band exhibits peak VSWR 3.96 when the gap value is taken as $g_{4}=2.2 \mathrm{~mm}$ and the circular shaped split ring is able to achieve desired X-band notching. The effective inductance of the circular-shaped split ring decreases when its length decreases, i.e., the gap size $g_{4}$ increases, which helps in attaining the higher resonance frequency.

The simulated radiation patterns are also obtained in E-plane $\left(\mathrm{phi}=0^{\circ}\right)$ and $\mathrm{H}$-plane $\left(\mathrm{phi}=90^{\circ}\right)$ (principal planes) at selected frequencies $3.18 \mathrm{GHz}, 4.74 \mathrm{GHz}, 6.38 \mathrm{GHz}$, and $8.8 \mathrm{GHz}$, and these results are represented in Figures 11-14, respectively. The simulated result shows that the proposed antenna exhibits dipole-like radiation pattern in E-plane and omni-directional radiation pattern in $\mathrm{H}$-plane. The small variation at higher frequency is due to cross polarisation and 

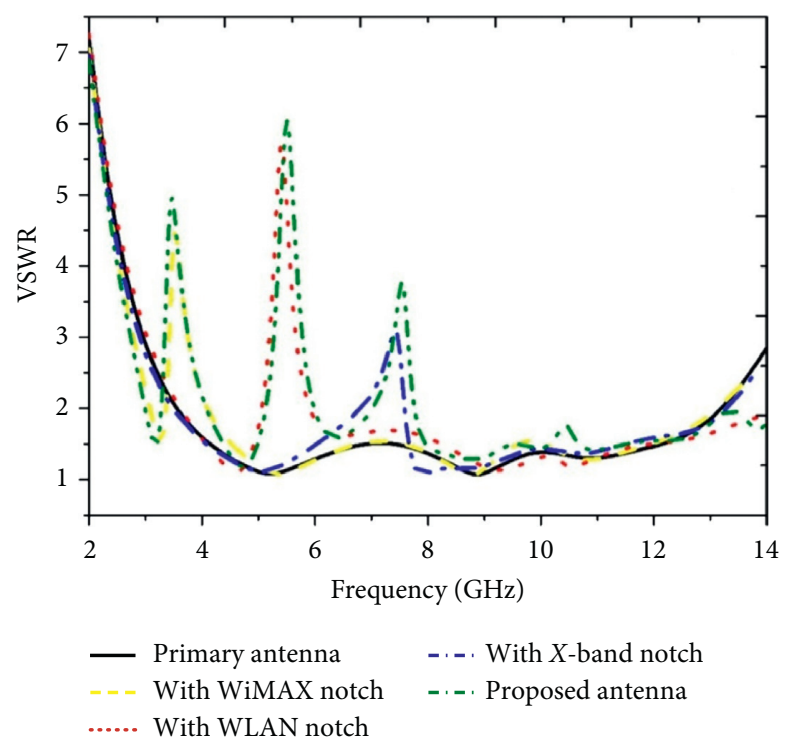

FIgURE 4: VSWR result for the proposed antenna.

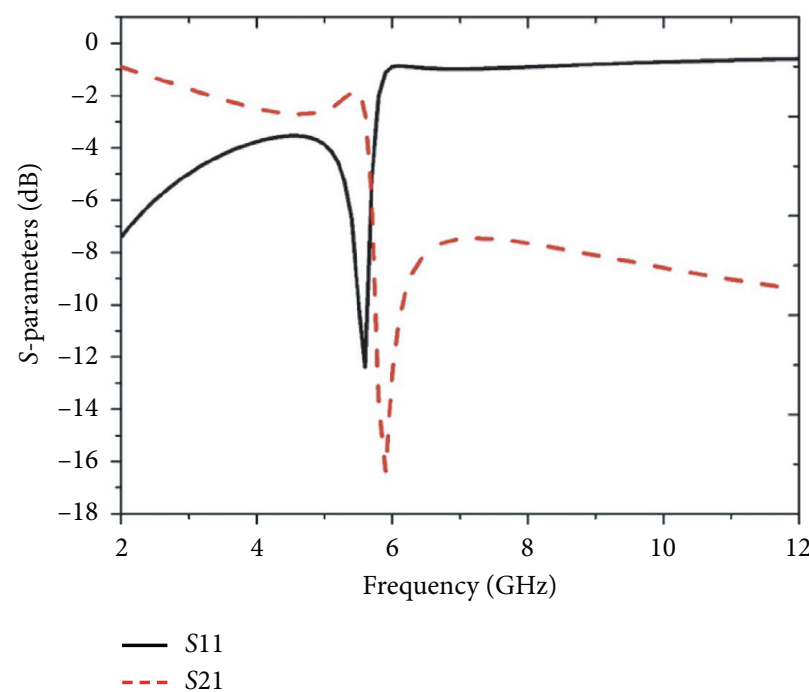

FIgURE 5: Scattering parameter result of the metamaterial SRR unit cell.

radiation pattern is distorted, whereas in $\mathrm{H}$-plane the radiation pattern is perfectly omni-directional at all frequencies of pass bands.

The gain versus frequency variation for the proposed band notched antenna is illustrated in Figure 15. It can be seen from Figure 15 that there is a sharp decrease in gain at notched frequencies with the negative value of gain $-8.45 \mathrm{~dB}$ at $3.4 \mathrm{GHz},-13.04 \mathrm{~dB}$ at $5.5 \mathrm{GHz}$, and $-3.42 \mathrm{~dB}$ at $7.6 \mathrm{GHz}$ along the peak gain value of $3.7 \mathrm{~dB}$ with stable gain over the pass band frequencies. Figure 16 shows the radiation efficiency of the suggested antenna which is nearly $85-90 \%$ over pass bands and at the notched bands; radiation efficiency is
$34 \%, 22 \%$, and $48 \%$ at $3.42 \mathrm{GHz}, 5.5 \mathrm{GHz}$, and $7.58 \mathrm{GHz}$, respectively.

Furthermore, the comparison of proposed prototype planar band notch antenna with few other existing antennas is done and represented in Table 3. From this Table 3, we can conclude that the proposed UWB band notched antenna loaded with metamaterial-inspired SRR and slots is compact in dimensions and novel and functional for ultrawide band applications with rejected band characteristics at WiMAX, C-band, WLAN band, and downlink X-band satellite communication. The present work also exhibits a good gain of $3.7 \mathrm{~dB}$ compared to other existing antennas. 


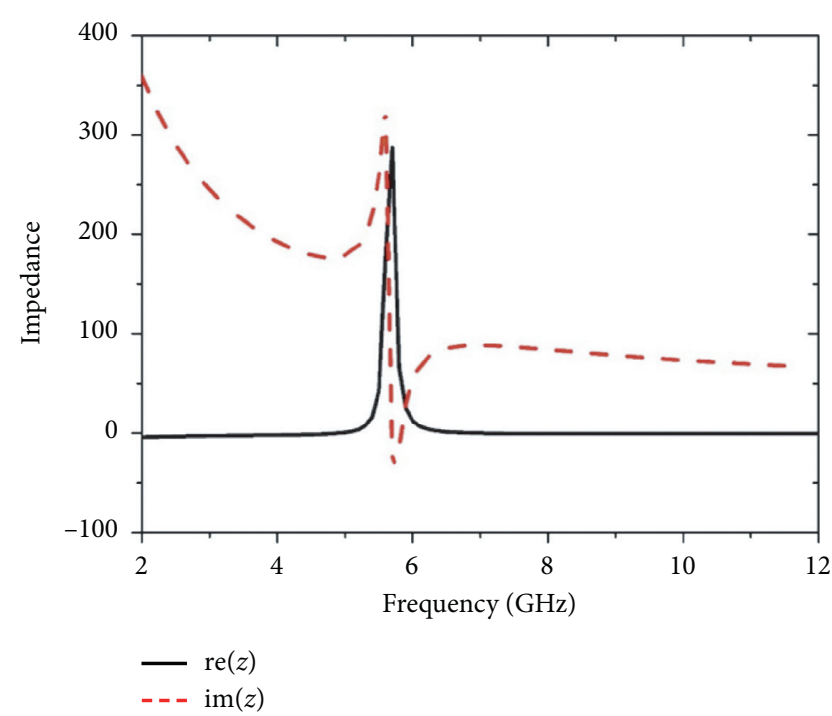

FIgUre 6: Impedance of the metamaterial unit cell.

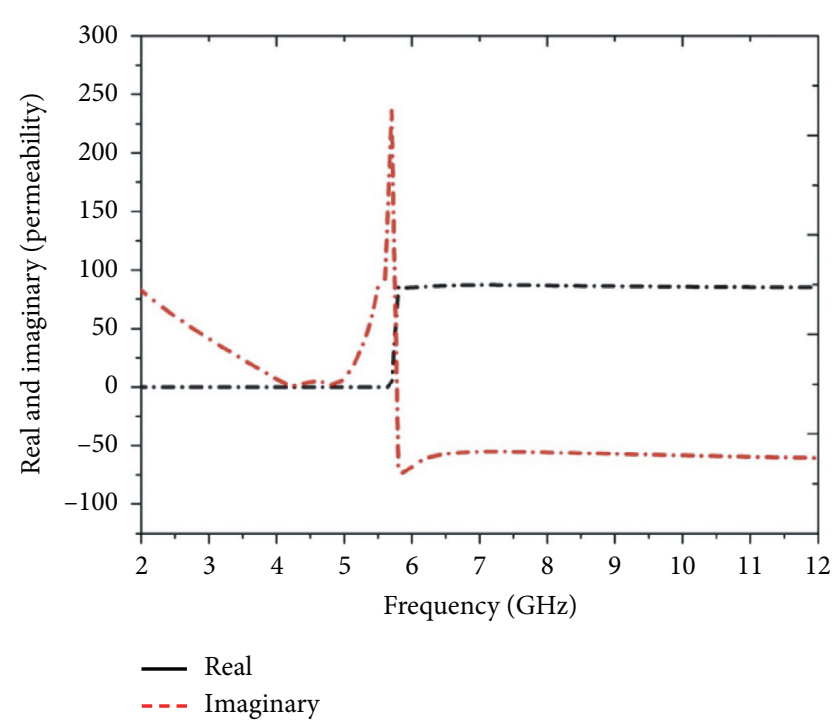

FIGURE 7: Extracted negative permeability of the metamaterial unit cell.

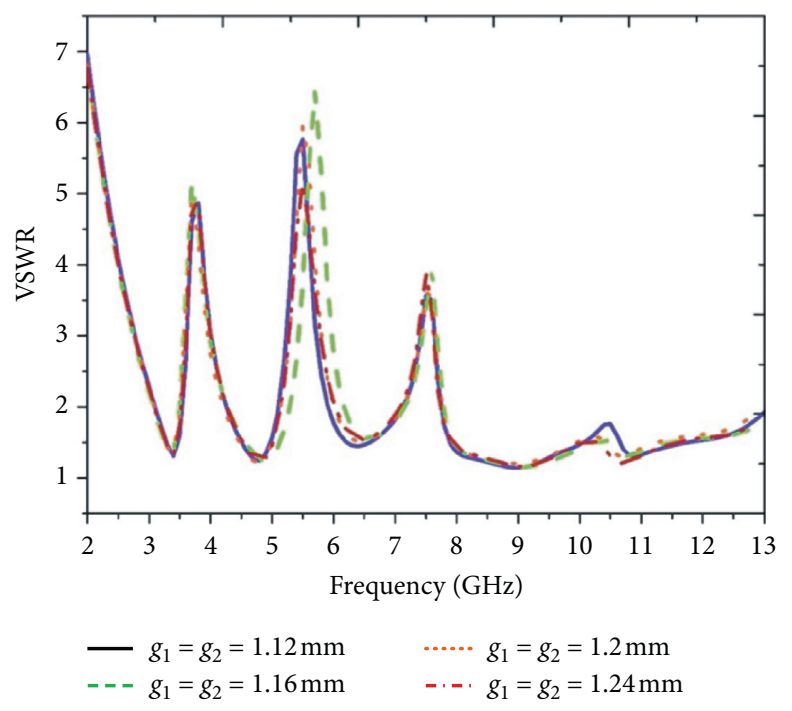

FIGURE 8: Variation of gap $g_{1}$ and $g_{2}$ for optimization of WLAN band notching.

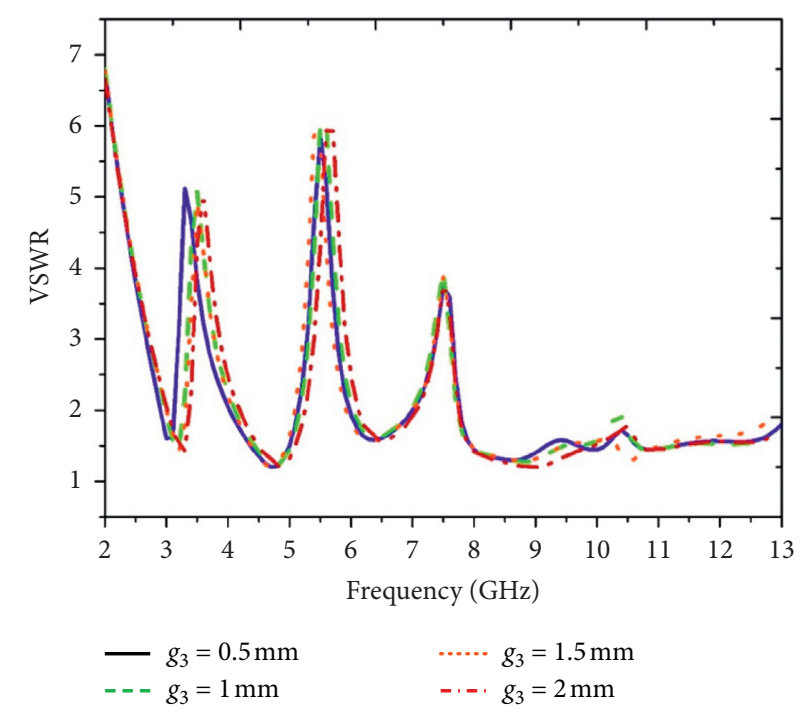

FIgURE 9: Variation of gap $g_{3}$ for optimization of WiMAX and Cband notching. 


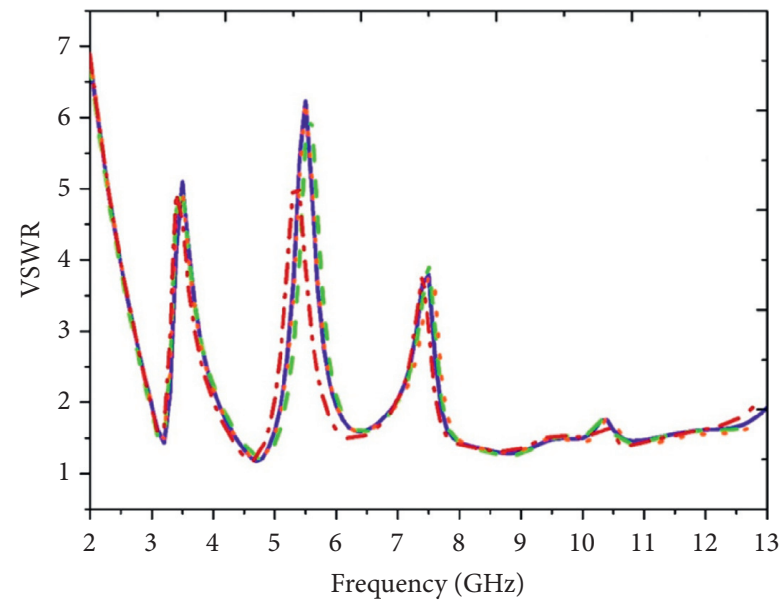

$$
\begin{array}{ll}
-g_{4}=2.16 \mathrm{~mm} & \cdots \cdots g_{4}=2.2 \mathrm{~mm} \\
=--g_{4}=2.18 \mathrm{~mm} & \quad--g_{4}=2.22 \mathrm{~mm}
\end{array}
$$

FIgURE 10: Variation of gap $g_{4}$ for optimization of downlink X-band notching.

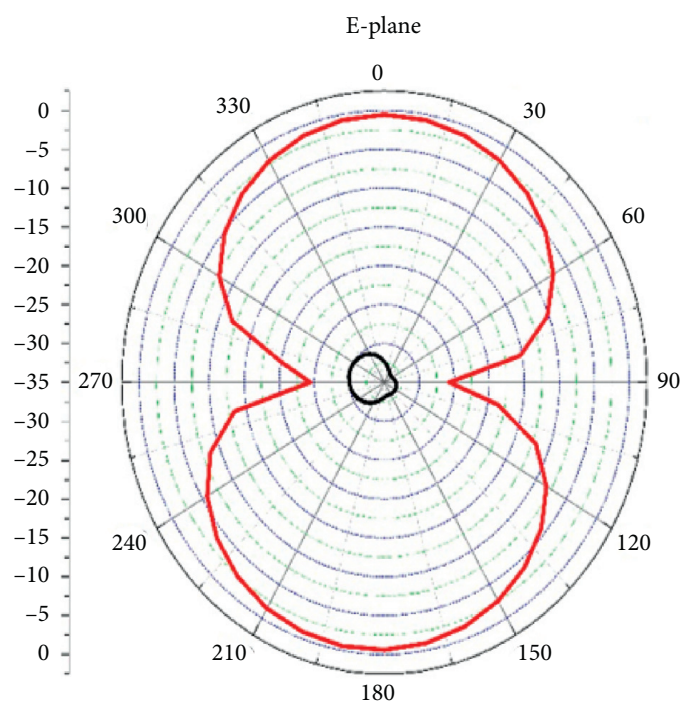

- Cross-polarisation

Co-polarisation

(a)

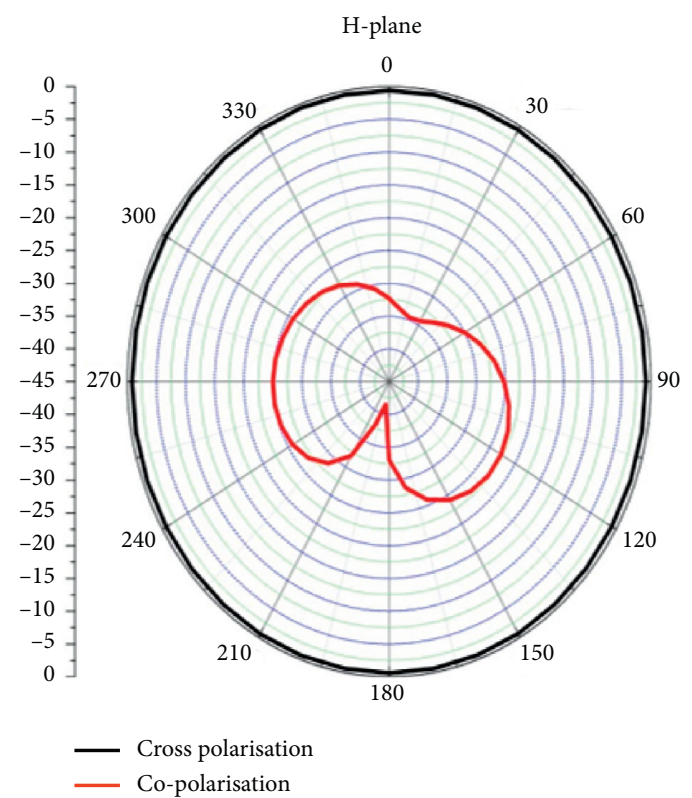

(b)

FIGURE 11: Simulated radiation patterns in E-plane and H-plane at frequency of $3.18 \mathrm{GHz}$. 


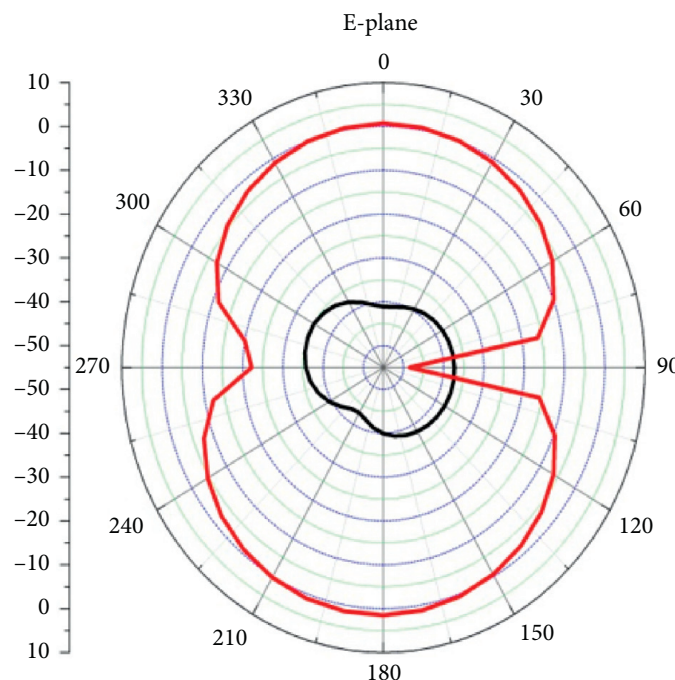

Cross-polarisation Co-polarisation

(a)

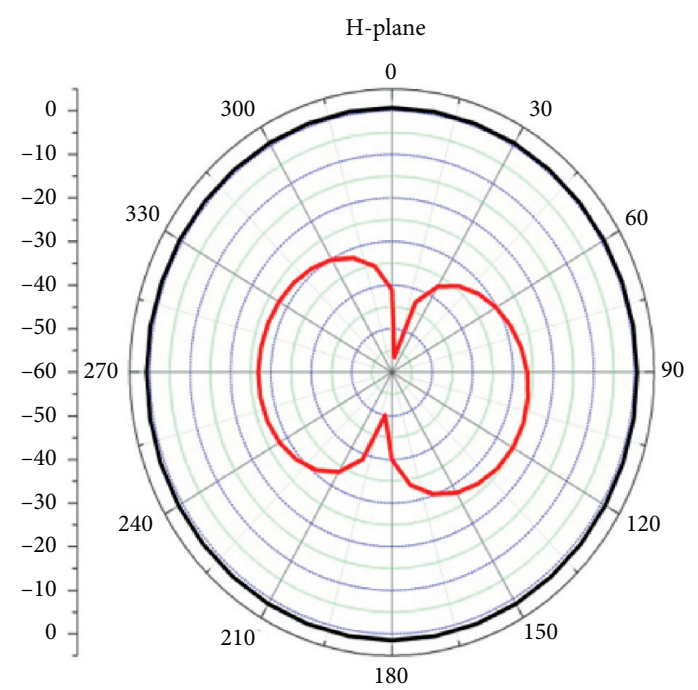

- Cross polarisation

- Co-polarisation

(b)

Figure 12: Simulated radiation patterns in E-plane and H-plane at frequency of $4.74 \mathrm{GHz}$.

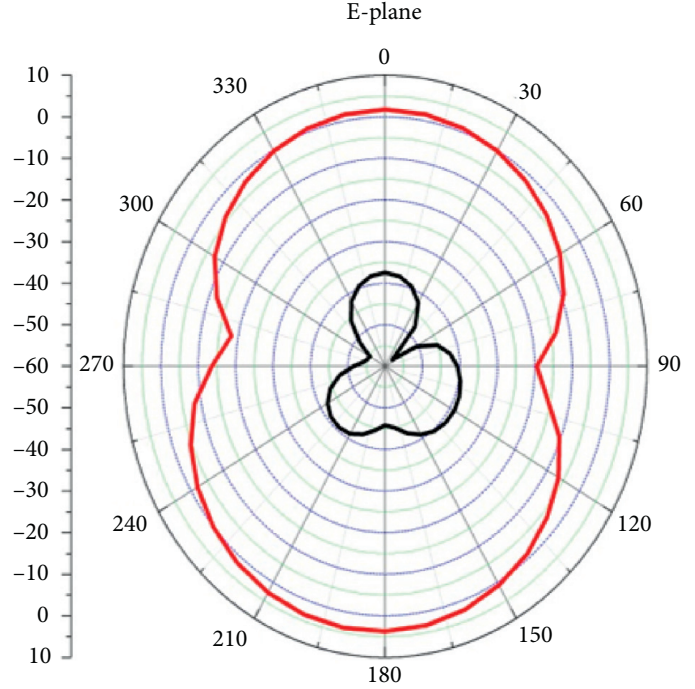

- Cross polarisation

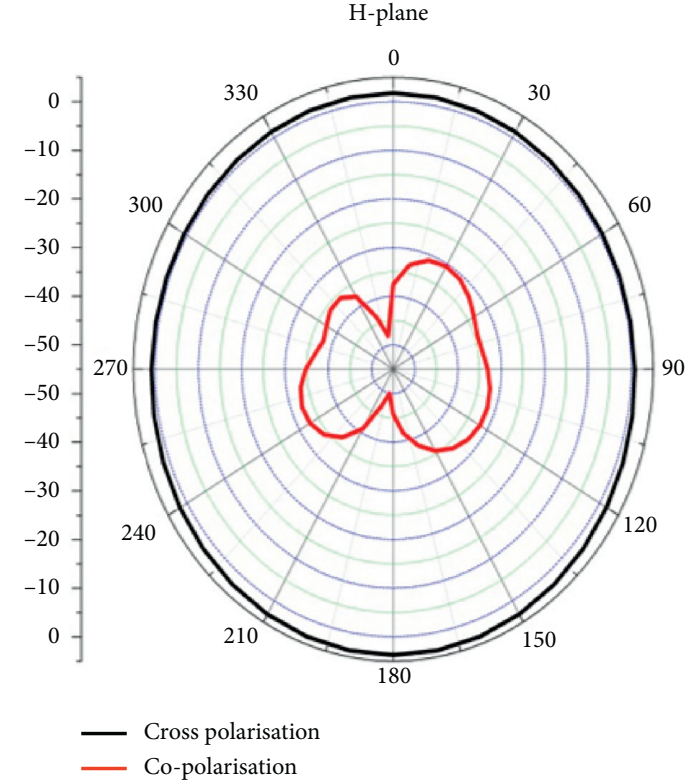

(b)

Figure 13: Simulated radiation patterns in E-plane and H-plane at frequency of $6.38 \mathrm{GHz}$. 


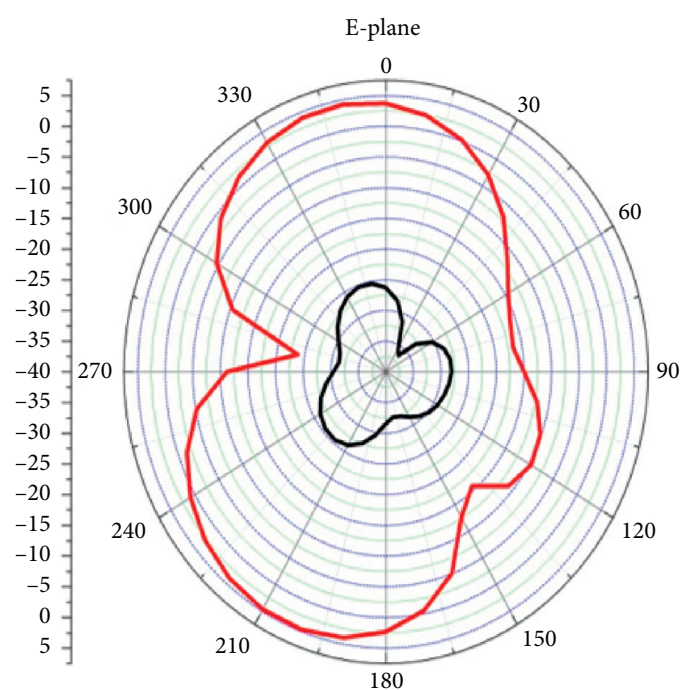

Cross polarisation Co-polarisation

(a)

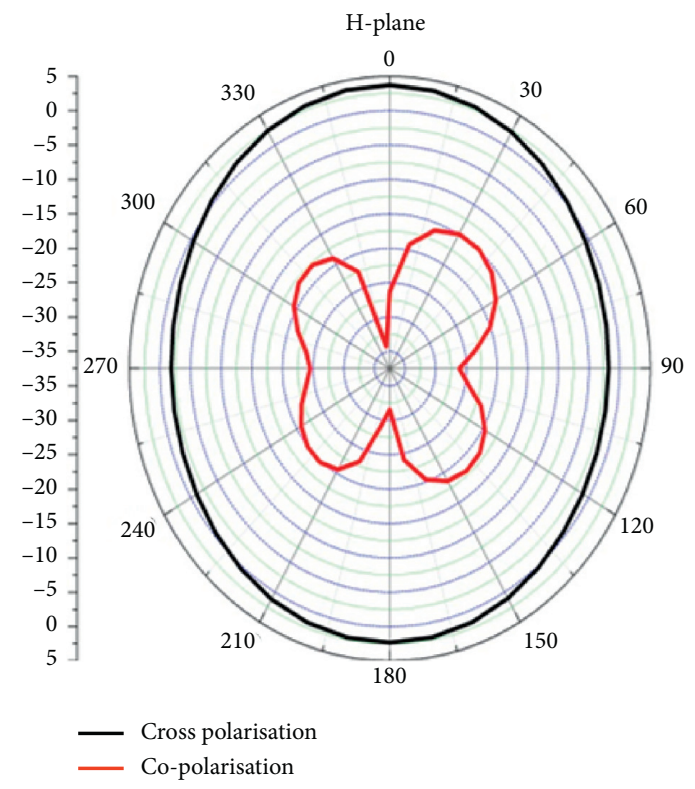

(b)

Figure 14: Simulated radiation patterns in E-plane and H-plane at frequency of $8.8 \mathrm{GHz}$.

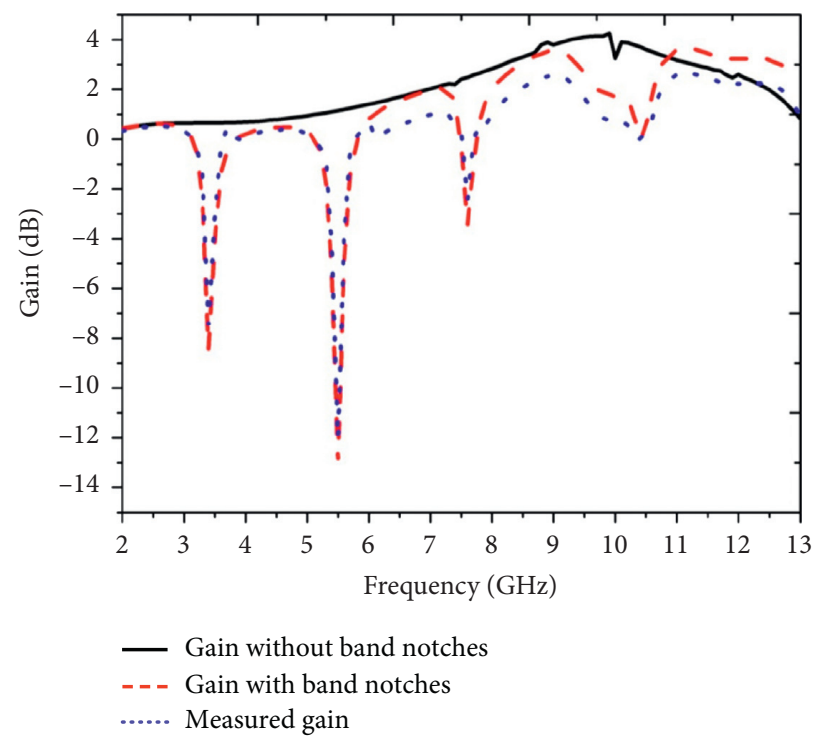

FIGURE 15: Gain of the proposed antenna with and without notches. 


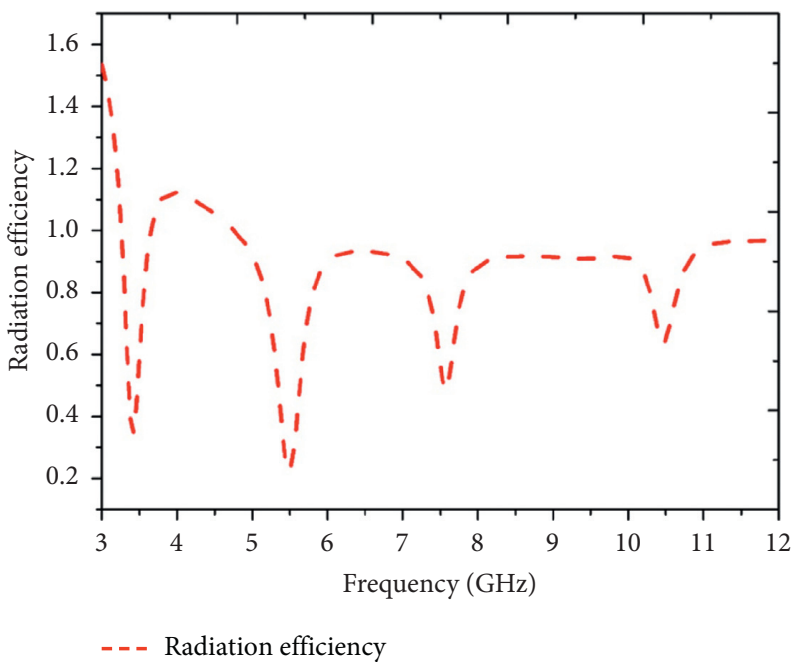

FIgURE 16: Simulated radiation efficiency of the proposed antenna.

TABLE 3: Comparison of the proposed antenna with various existing antennas.

\begin{tabular}{lccc}
\hline References & Dimensions & Notched bands & Gain $(\mathrm{dB})$ \\
\hline$[6]$ & $30 \times 30 \times 1.6 \mathrm{~mm}^{3}$ & WiMAX/WLAN-band & WLAN/X-band \\
{$[39]$} & $19 \times 16 \times 1.6 \mathrm{~mm}^{3}$ & WiMAX/WLAN/X-band & $<2$ \\
{$[40]$} & $42 \times 24 \times 1.6 \mathrm{~mm}^{3}$ & C-band/WLAN/X-band & 3 \\
{$[41]$} & $38 \times 20 \times 0.58 \mathrm{~mm}^{3}$ & WiMAX/WLAN/X-band \\
{$[42]$} & $20 \times 20 \times 1.6 \mathrm{~mm}^{3}$ & WiMAX/WLAN/X-band \\
{$[43]$} & $35 \times 35 \times 1.6 \mathrm{~mm}^{3}$ & WiMAX/WLAN-band & 2.8 \\
{$[46]$} & $26 \times 30 \times 1.6 \mathrm{~mm}^{3}$ & WiMAX/WLAN-band & 3.9 \\
{$[47]$} & $31 \times 31 \times 1.6 \mathrm{~mm}^{3}$ & WiMAX/WLAN-band & 3.6 \\
{$[48]$} & $78 \times 44.6 \times 1.6 \mathrm{~mm}^{3}$ & WiMAX/C-band/WLAN/X-band & 2.8 \\
Present work & $24 \times 20 \times 1.6 \mathrm{~mm}^{3}$ & \\
\hline
\end{tabular}

\section{Conclusions}

A compact size metamaterial-inspired split ring resonator loaded antenna with band stop characteristics is proposed. The proposed antenna is able to provide a wide bandwidth from 3.1 GHz to $14 \mathrm{GHz}$ with frequency rejection characteristics. By etching split ring resonator slot on top of patch, two band notches, one at WiMAX band and other at C-band, are achieved. The WLAN band stop characteristic is accomplished by entrenching the metamaterial-inspired SRR structure near the feed line of the suggested antenna. The next notching of downlink of X-band satellite communication is achieved by utilizing the split ring circular-shaped slot at the centre of the radiating patch. It is observed from the parametric study that the band notching at different frequencies can be tuned and controlled independently by adjusting the dimensions of SRR structure and slots. The presented antenna is compact and also excellent to suppress the interference of existing bands (WiMAX, C-band, WLAN-band, and X-band satellite communication signal) from the UWB pass band. The proposed antenna exhibits negative gain at notch frequencies with a peak gain of $3.7 \mathrm{~dB}$. The presented work also exhibits the good radiation efficiency of nearly $85-90 \%$ over pass bands and $34 \%$, $22 \%$, and $48 \%$ at $3.42 \mathrm{GHz}, 5.5 \mathrm{GHz}$, and $7.58 \mathrm{GHz}$, respectively. The simulated results show good agreement with the measured result. The results of the proposed antenna show that it is a suitable candidate for wireless applications.

\section{Data Availability}

The data used to support the findings of the study are available from the corresponding author upon request.

\section{Conflicts of Interest}

The authors declare that there are no conflicts of interest regarding the publication of this article.

\section{References}

[1] S. John, "Strong localization of photons in certain disordered dielectric superlattices," Physical Review Letters, vol. 58, no. 23, pp. 2486-2489, 1987.

[2] D. Bhattacharya, "Ultra-Wide band microstrip patch antenna design for wireless application," International Journal of Engineering Research and Technology (IJERT), vol. 1, no. 9, pp. 1-4, 2012.

[3] A. Zakriti, N. A. Touhami, M. El Ouahabi, and M. Lamsalli, "Design of a compact CPW fed antenna for UWB applications," International Journal of Microwave and Optical Technology, vol. 10, no. 5, pp. 15-20, 2015. 
[4] Z. Li, C.-X. Zhang, G.-M. Wang, and W.-R. Su, "Designs on CPW-fed aperture antenna for ultra-wideband applications," Progress in Electromagnetics Research C, vol. 2, pp. 1-6, 2008.

[5] K. G. Thomas and M. Sreenivasan, "Compact CPW-fed dualband antenna," Electronics Letters, vol. 46, no. 1, pp. 13-14, 2010.

[6] L. Cui, H. Liu, C. Hao, and X. Sun, "A novel UWB antenna with triple band-notches for WiMAX and WLAN," Progress in Electromagnetics Research Letters, vol. 82, pp. 101-106, 2019.

[7] S. R. Kenny and A. K. Ahmed, "UWB antenna with signle or dual band-notches for lower WLAN band and upper WLAN band," IEEE Transactions on Antennas and Propagation, vol. 57, pp. 3942-3950, 2009.

[8] A. Alhegazi, Z. Zakaria, N. A. Shairi, I. M. Ibrahim, and S. Ahmed, "A novel reconfigurable UWB filtering-antenna with dual sharp band notches using double split ring resonators," Progress In Electromagnetics Research C, vol. 79, pp. 185-198, 2017.

[9] M. G. Wahab, W. Swelam, and M. N. Abdeazeem, "Miniaturized UWB antenna with triple band-notched characteristics utilizing SRR and folded U-shaped slot," in Proceedings of the Progress in Electromagnetics Research Symposium, St. Petersburg, Russia, May 2017.

[10] N. Sharma, S. S. Bhatia, V. Sharma, and J. S. Sivia, "An octagonal shaped monopole antenna for UWB applications with band notch characteristics," Wireless Personal Communications, vol. 111, no. 3, pp. 1977-1997, 2020.

[11] Z.-H. Tu, A.-L. Wen, and Q.-X. Chu, "Single-layer differential CPW-feed notch-band tapered-slot UWB antenna," IEEE Antennas and Wireless Propagation Letters, vol. 13, pp. 1296-1299, 2014

[12] T. Yan, D. Lu, X.-H. Tang, and J. Xiang, "High-selectivity UWB bandpass filter with a notched band using stub-loaded multi-mode resonator," AEU-International Journal of Electronics and Communications, vol. 70, no. 12, pp. 1617-1621, 2016.

[13] R. Chandel and A. K. Gautam, "Compact MIMO/diversity slot antenna for UWB applications with band-notched characteristic," Electronics Letters, vol. 52, no. 5, pp. 336-338, 2016.

[14] Z. Liu, X. Wu, Y. Zhang, P. Ye, Z. Ding, and C. Hu, "Very compact $5.5 \mathrm{Ghz}$ band-notched UWB-mimo antennas with high isolation," Progress in Electromagnetics Research C, vol. 76, pp. 109-118, 2017.

[15] N. Mohammadian, M.-N. Azarmanesh, and S. Soltani, "Compact ultra-wideband slot antenna fed by coplanar waveguide and microstrip line with triple-band-notched frequency function," IET Microwaves, Antennas \& Propagation, vol. 4, no. 11, pp. 1811-1817, 2010.

[16] J.-Y. Deng, Y.-Z. Yin, S.-G. Zhou, and Q.-Z. Liu, "Compact ultra-wideband antenna with tri-band notched characteristic," Electronics Letters, vol. 44, no. 21, p. 1231, 2008.

[17] Z. Mansouri, A. S. Arezoomand, S. Heydari, and F. B. Zarrabi, "Dual notch UWB fork monopole antenna with CRLH metamaterial load," Progress In Electromagnetics Research C, vol. 65, pp. 111-119, 2016.

[18] T. A. Denidni and Z. Weng, "Hybrid ultrawideband dielectric resonator antenna and band-notched designs," IET Microwaves, Antennas \& Propagation, vol. 5, no. 4, pp. 450-458, 2011.

[19] M. Moosazadeh, A. M. Abbosh, and Z. Esmati, "Design of compact planar ultrawideband antenna with dual-notched bands using slotted square patch and pi-shaped conductor- backed plane," IET Microwaves, Antennas \& Propagation, vol. 6, no. 3, pp. 290-294, 2012.

[20] Y.-L. Zhao, Y.-C. Jiao, G. Zhao, L. Zhang, Y. Song, and Z.-B. Wong, "Compact planar monopole UWB antenna with band-notched characteristic," Microwave and Optical Technology Letters, vol. 50, no. 10, pp. 2656-2658, 2008.

[21] W. T. Li, X. W. Shi, and Y. Q. Hei, "Novel planar UWB monopole antenna with triple band notched characteristics," IEEE Antennas and Wireless Propagation Letters, vol. 8, pp. 1094-1098, 2009.

[22] K.-H. Kim, Y.-J. Cho, S.-H. Hwang, and S.-O. Park, "Bandnotched UWB planar monopole antenna with two parasitic patches," Electronics Letters, vol. 41, no. 14, pp. 783-785, 2005.

[23] M. Abbosh and M. E. Bialkowski, "Design of UWB planar band-notched antenna using parasitic elements," IEEE Transactions on Antennas and Propagation, vol. 57, pp. 796799, 2009.

[24] H. Medkour, M. Cheniti, A. Narbudowicz et al., "Coplanar waveguide-based ultra-wide band antenna with switchable filtering of WiMAX $3.5 \mathrm{GHz}$ and WLAN $5 \mathrm{GHz}$ signals," Microwave and Optical Technology Letters, vol. 62, no. 6, pp. 2398-2404, 2020.

[25] A. Gorai and R. Ghatak, "Multimode resonator-assisted dual band notch UWB antenna with additional bluetooth resonance characteristics," IET Microwaves, Antennas \& Propagation, vol. 13, pp. 1854-1859, 2019.

[26] R. Mondal, P. S. Reddy, D. C. Sarkar, and P. P. Sarkar, "Compact ultra-wideband antenna: improvement of gain and FBR across the entire bandwidth using FSS," IET Microwaves, Antennas \& Propagation, vol. 14, no. 1, pp. 66-74, 2020.

[27] M. S. Khan, A. D. Capobianco, A. Naqvi, M. F. Shafique, B. Ijaz, and B. D. Braaten, "Compact planar UWB MIMO antenna with on-demand WLAN rejection," Electronics Letters, vol. 51, no. 13, pp. 963-964, 2015.

[28] R. Azim, M. T. Islam, and A. T. Mobashsher, "Design of a dual band-notch UWB slot antenna by means of simple parasitic slits," IEEE Antennas and Wireless Propagation Letters, vol. 12, pp. 1412-1415, 2013.

[29] A. Sharma and M. M. Sharma, "An UWB antenna design with dual band notched characteristic using U-shaped slots," in Proceedings of the IEEE International Conference on Signal Processing and Communication, Noida, India, December 2016.

[30] A. R. Azeez, T. A. Elwi, and Z. A. Abed Al-Hussain, "Design and analysis of a novel concentric rings based crossed lines single negative metamaterial structure," Engineering Science and Technology, An International Journal, vol. 20, no. 3, pp. 1140-1146, 2017.

[31] J. B. Pendry, A. J. Holden, D. J. Robbins, and W. J. Stewart, "Magnetism from conductors and enhanced nonlinear phenomena," IEEE Transactions on Microwave Theory and Techniques, vol. 47, no. 11, pp. 2075-2084, 1999.

[32] X. Zhang, T.-L. Zhang, Y.-Y. Xia, Z.-H. Yan, and X.-M. Wang, "Planar monopole antenna with band-notch characterization for UWB applications," Progress in Electromagnetics Research Letters, vol. 6, pp. 149-156, 2009.

[33] D. O. Kim, N.-I. Jo, D.-M. Choi, and C.-Y. Kim, "Design of the ultrawide band antenna $5.2 \mathrm{GHz} / 5.8 \mathrm{GHz}$ band rejection using rectangular split-ring resonators (SRRS) loading," Journal of Electromagnetic Waves and Application, vol. 23, pp. 2503-2512, 2009.

[34] S. Thorat and R. Kumar, "Design of rectangular-cut circular disc UWB antenna with band-notched characteristics," 
International Journal of Engineering Science and Technology (IJEST), vol. 4, no. 4, pp. 1685-1692, 2012.

[35] G. Dhiman and V. Kumar, "Spotted hyena optimizer: a novel bio-inspired based metaheuristic technique for engineering applications," Advances in Engineering Software, vol. 114, pp. $48-70,2017$.

[36] A. Kumar, V. Jagota, R. Q. Shawl et al., "Wire EDM process parameter optimization for D2 steel," Materials Today: Proceedings, vol. 37, no. 2, pp. 2478-2482, 2021.

[37] G. Dhiman and V. Kumar, "Multi-objective spotted hyena optimizer: a multi-objective optimization algorithm for engineering problems," Knowledge-Based Systems, vol. 150, pp. 175-197, 2018.

[38] J. N. Lee and J. K. Park, "Impedance characteristics of trapezoidal ultra-wideband antennas with a notch function," Microwave and Optical Technology Letters, vol. 46, no. 5, pp. 503-506, 2005.

[39] R. Mittra, "A critical look at metamaterials for antenna related applications," Journal of Communications Technology and Electronics, vol. 52, no. 9, pp. 1051-1058, 2007.

[40] J. D. Baena, J. Bonache, F. Martin et al., "Equivalent-circuit models for split-ring resonators and complementary splitring resonators coupled to planar transmission lines," IEEE Transactions on Microwave Theory and Techniques, vol. 53, no. 4, pp. 1451-1461, 2005.

[41] D.-O. Kim, N.-I. Jo, H.-A. Jang, and C.-Y. Kim, "Design of the ultrawideband antenna with a quadruple-band rejection characteristics using a combination of the complementary split ring resonators," Progress in Electromagnetics Research, vol. 112, pp. 93-107, 2011.

[42] D. Patir and D. K. Neog, "Metamaterial based step shape patch antenna for wireless application," International Journal of Advanced Research in Science, Engineering and Technology, vol. 3, no. 6, pp. 2233-2237, 2016

[43] H. M. Asma, S. A. Abdulkareem, H. Khalil et al., "Compact dielectric resonator antenna with band-notched characteristics for ultra-wideband applications," Progress in Electromagnetics Research C, vol. 57, pp. 137-148, 2015.

[44] K. Jairath and N. Singh, "A novel WLAN and X-band rejected elliptical slot loaded metamaterial inspired antenna," Materials Today: Proceedings, 2021.

[45] S. Vimal and P. Subbulakshmi, "Secure data packet transmission in MANET using enhanced identity-based cryptography," International Journal of New Technologies in Science and Engineering, vol. 3, no. 12, pp. 35-42, 2016.

[46] S. Gopikumar, S. Raja, Y. Harold Robinson, V. Shanmuganathan, H. Chang, and S. Rho, "A method of landfill leachate management using internet of things for sustainable smart city development," Sustainable Cities and Society, vol. 66, p. 102521, 2020.

[47] Q. X. Chu and Y. Y. Yang, "A compact ultrawideband antenna with $3.5 / 5.5 \mathrm{GHz}$ dual band notched characteristic," IEEE Transactions on Antennas and Propagation, vol. 56, no. 12, pp. 3637-3644, 2008.

[48] A. Chaabane, F. Djahli, and S. Redadaa, "A dual-bandnotched antenna for UWB communication systems using two different shaped slots," Arabian Journal for Science and Engineering, vol. 39, no. 8, pp. 6215-6223, 2014. 